\title{
SYSTEMATIC LITERATURE REVIEW : EFEKTIVITAS SISTEM INFORMASI AKUNTANSI KOPERASI DI INDONESIA
}

\author{
Tari Dwi Rachmawati ${ }^{1}$, Dwi Cahyono ${ }^{2}$, Ari Sita Nastiti ${ }^{3}$ \\ 1,2,3Universitas Muhammadiyah Jember, taridwir@gmail.com
}

\begin{abstract}
ABSTRAK
Penelitian ini bertujuan untuk mengisi kesenjangan penelitian dengan memberikan tinjauan pustaka sistematis mengenai faktor yang mempengaruhi efektivitas sistem informasi akuntansi pada koperasi di Indonesia. Metode penelitian ini menggunakan proses tinjauan pustaka sistematis yang terdiri dari tiga tahapan yaitu, perencanaan, pelaksanaan dan pelaporan. Studi awal yang ditemukan 316 artikel penelitian, dan total studi yang digunakan 10 untuk tinjauan pustaka sistematis ini berdasarkan kriteria inklusi dan eksklusi. Terdapat empat properti ekstraksi data yang dapat bermanfaat dalam menjawab pertanyaan penelitian. Hasil tinjauan pustaka sistematis dari semua penelitian yang terdapat pada jurnal yang dipublikasikan dari tahun 2015 sampai tahun 2020 menyatakan bahwa faktor yang mempengaruhi efektivitas sistem informasi akuntansi koperasi di Indonesia sangatlah beragam yaitu adanya faktor kemampuan teknik personal, keterlibatan pemakai, pemanfaatan teknologi, usia, tingkat pendidikan, program pelatihan dan pendidikan, pengalaman kerja, pengetahuan karyawan di bagian akuntansi, kecanggihan teknologi informasi, kinerja individu, kompleksitas tugas, formalisasi pengembangan sistem, dukungan manajer, ukuran perusahaan, keberadaan dewan pengarah, serta lokasi departemen pengarah. Faktor utama yang mempengaruhi ialah keterlibatan pemakai dimana koperasi sebaiknya memberikan pendidikan serta pelatihan program sistem informasi akuntansi sehingga dapat meningkatkan keahlian yang dimiliki pemakai dan mampu mengefektivkan sistem informasi akuntansi serta membuat keputusan.
\end{abstract}

Kata Kunci: Tinjauan Pustaka Sistematis, Efektivitas Sistem Informasi Akuntansi, Koperasi

\begin{abstract}
This study aims to fill the research gap by providing a systematic literature review of the factors that influence the effectiveness of the accounting information system in cooperative in Indonesia. This research method uses a systematic literature review process which consists of three stages, namely, planning, implementation and reporting. The initial study found 316 research articles, and used a total of 10 studies for this systematic literature review based on inclusion and exclusion criteria. The extraction of selected primary research, selected and collected quantitative data will help answer a question in this research. The results of a systematic literature review of all research contained in journals published from 2015 to 2020 state that the factors that influence the effectiveness of cooperative accounting information systems in Indonesia are very diverse, namely the existence of factors of personal technical ability, user involvement, technology utilization, age, education level. , training and education programs, work experience, employee knowledge in accounting, the sophistication of information technology, individual performance, task complexity, system development formalization, manager support, company size, the presence of a steering committee, and the location of the steering department. The main factor that influences is user involvement where the cooperative should
\end{abstract}


provide education and training in accounting information system programs so as to increase the user's expertise and be able to make accounting information systems effective and make decisions. Keywords: Systematic Literature Review, Effectiveness of accounting information systems, Cooperative

Naskah diterima : 26-03-2021, Naskah dipublikasikan : 31-03-2021

\section{PENDAHULUAN}

Krisiani dan Dewi (2013) melaporkan bahwa memiliki sistem informasi akuntansi yang efektif adalah suatu cara mencapai keberhasilan untuk mendirikan koperasi. Efektivitas sistem informasi akuntansi adalah tolak ukur dalam memberikan gambaran tentang dimana tujuan yang sudah direncanakan terlaksana dari sekumpulan sumber daya yang diatur dalam menghimpun, mengolah, dan menyimpan data elektronik, kemudian diubah menjadi informasi yang bermanfaat dan sebagai penyediaan laporan formal yang dibutuhkan dengan berkualitas, bagus, serta mampu mempersingkat waktu bagi pengguna.

Kharisma dan Dharmadiaksa (2015) menyatakan bahwa faktor karyawan perusahaan adalah suatu faktor yang perlu diperhatikan perusahaan untuk mengimplementasikan sistem informasi akuntansi. Seberapa baik prosedur tersebut dapat diterapkan untuk memperoleh informasi yang bermanfaat untuk perusahaan. Implementasi sistem informasi akuntansi yang efektif bisa membuat laporan akan lebih cepat terselesaikan. Informasi yang terkandung didalam laporan keuangan sangat penting untuk dilaporkan secara tepat dan akurat, dimana laporan akuntansi merupakan informasi mengenai perusahaan yang dapat membuka peluang strategis perusahaan dimasa depan (Ramazani dan Allahyari, 2013).

Penggunaan sistem informasi akuntansi yang efektif, wajib diikuti melalui pelaksanaan program pelatihan dan pendidikan untuk meningkatkan keahlian pekerja serta mampu menyampaikan ilmu yang sangat banyak tentang pemakaian sistem komputer. Tenaga yang ahli bisa menggunakan sistem informasi akuntansi dengan sangat efektif serta membawa keuntungan untuk instansi (Halimatusadiah, Nurhayati dan Rayandani, 2015). Kompetensi individual para pekerja lebih diutamakan oleh instansi. Kemampuan karyawan dalam bekerja dan menyelesaikan tugas dapat ditunjukkan dengan perkembangan sistem akuntansi yang ada di perusahaan. Karyawan yang berpengalaman kerja termasuk dalam kemampuan individual. Karyawan yang memiliki banyak pengalaman dalam menggunakan sistem informasi akuntansi akan dapat bergerak dengan lancar serta mampu merespon dengan cepat dalam menanggapi kesulitan yang dihadapi saat menghasilkan informasi (Dwijayanthi dan Dharmadiaksa, 2013).

Penggunaan teknologi maupun sistem sekarang telah menyebar ke segala bidang bisnis, tidak hanya untuk dikalangan perusahaan saja, tetapi koperasi yang menjadikan kalangan masyarakat menengah sebagai pangsa pasar pun sudah menggunakan sistem serta teknologi. Selain jalur koperasi yang lebih mudah dijangkau masyarakat, yang mendukung semakin banyak koperasi di Indonesia sekarang dikarenakan pertumbuhan ekonomi di Indonesia (Trino, 2013). Sari dan Indraswarawati (2020) melaporkan bahwa penggunaan sistem informasi akuntansi di koperasi masih belum optimal, dikarenakan beberapa kegiatan masih mengandalkan Microsoft excel dan pembukuan manual daripada teknik yang otomatis. Oleh karena itu, anggota akan mengalami pelayanan yang lebih lambat dan berdampak pada laporan yang diperlukan serta mempengaruhi cara kerja koperasi secara menyeluruh dan kepercayaan masyarakat menurun. 
Riset mengenai efektivitas sistem informasi akuntansi sudah banyak dilakukan. Banyaknya riset tersebut akan menyebabkan ketidakonsistenan atas hasil riset. Sejauh ini, belum ada systematic literature review yang mengulas mengenai efektivitas sistem informasi akuntansi koperasi di Indonesia. Maka dari itu, riset ini dibuat menggunakan metode studi kepustakaan serta memberikan informasi dengan mengkaji terhadap penelitian sebelumnya, yang bertujuan untuk mengisi kesenjangan penelitian dengan memberikan analisis efektivitas sistem informasi akuntansi pada koperasi secara luas.

\section{KAJIAN LITERATUR \\ Systematic Literature Review (SLR)}

Systematic literature review atau tinjauan pustaka sistematis merupakan metode yang digunakan untuk menentukan, mengevaluasi, dan menginterpretasikan semua temuan masalah riset dalam menjawab pertanyaan yang sudah ditentukan. Pendekatan systematic literature review (SLR) dilakukan dengan terstruktur serta mengikuti tahapan, aturan, dan mampu menghindari pemahaman yang bersifat subjektif dari peneliti (Kitchenham et al., 2007).

\section{Sistem Informasi Akuntansi}

Sistem Informasi Akuntansi merupakan gabungan penyatuan dari subsistem fisik dan nonfisik yang berkaitan agar dapat mengatur bukti yang berhubungan dengan masalah keuangan menjadi informasi keuangan (Susanto, 2017). Sebuah metode yang ada di instansi yang mengumpulkan keperluan pemrosesan transaksi harian untuk berkontributif pengelolaan manfaat operasional badan perusahaan dan kegiatan strategis organisasi, sehingga bisa memberikan laporan kepada pihak eksternal tertentu merupakan penjelasan sistem informasi akuntansi (Tata, 2012). Penjelasan tersebut dapat disimpulkan jika sistem informasi akuntansi ialah elemen organisasi serta berguna saat mengelompokkan, mengarahkan, menata, dan mengamankan bukti atas segala tindakan yang berlangsung, hal tersebut dimanfaatkan untuk mengambil langkah yang signifikan dan berguna bagi perusahaan untuk mendapatkan informasi.

Romney dan Steinbart (2016) mengemukakan bagian sistem informasi akuntansi, yakni:

1. Pengguna sistemnya.

2. Proses beserta instruksi guna menyatukan, mengolah, dan merahasiakan data atau bukti.

3. Fakta tentang organisasi serta kegiatan bisnis lainnya.

4. Software yang berfungsi mengolah data.

5. Komputer yang difungsikan pada SIA

6. Pengawasan intern dan juga langkah keselamatan untuk mengarsip informasi SIA.

Diana dan Setiawati (2011) mengemukakan, ruang lingkup sistem informasi akuntansi mampu ditegaskan dengan kegunaan yang diperoleh melalui informasi akuntansi. Sistem informasi akuntansi berfungsi serta bertujuan untuk mengemukakan asset perusahaan, menghasilkan semua jenis informasi pengambilan keputusan, menghasilkan informasi dalam mengevaluasi kinerja karyawan, dan mendapatkan informasi untuk mempersiapkan, mengevaluasi anggaran perusahaan serta mampu memperoleh informasi yang dibutuhkan untuk merencanakan dan mengendalikan aktivitas organisasi. Berdasarkan tujuan sistem informasi akuntansi yang telah dijelaskan, maka bisa disimpulkan yaitu faktor utama yang terpenting untuk memperoleh informasi yang diperlukan setiap organisasi harus sesuai dan terstruktur.

\section{Efektivitas Sistem Informasi Akuntansi}

Efektivitas sistem informasi akuntansi adalah sebuah kesuksesan yang dicapai oleh sistem informasi akuntansi dalam mendapatkan penjelasan yang tepat, akurat, serta dipercaya 
(Ratnaningsih dan Suaryana, 2014). Hla dan Teru (2015) mengemukakan bahwa efektivitas sistem informasi akuntansi memiliki beberapa fungsi yaitu pengumpulan data, pemeliharaan, penyediaan data sistem informasi akuntansi dan pengetahuan manajemen, juga pemantauan keamanan data. Banyak faktor yang akan mempengaruhi efisiensi dan efektifitas sistem informasi akuntansi, baik pengguna, software, hardware, maupun kualifikasi database yang baik akan digunakan oleh instansi tersebut. Damayanthi (2012) menjelaskan bahwa efektivitas sistem informasi akuntansi adalah tolak ukur yang menguraikan sampai mana tujuan bisa diperoleh dari rangkaian kemampuan yang disusun guna mengumpulkan, mengoperasikan serta menyimpan data elektronik, yang selanjutnya menjadi sebuah penjelasan yang bermanfaat dan menyajikan laporan formal yang diperlukan dengan baik. Informasi akuntansi yang berkualitas sangat berguna meningkatkan efektivitas dan pengelolaan setiap organisasi sebab dapat menjadi dasar dari suatu usaha perorangan (Emeka-Nwokeji, 2012). Makin efektif sistem informasi akuntansi maka bertambah tinggi juga cara kerja perorangan (Novita, 2011). Berdasarkan definisi tersebut kesimpulannya adalah efektivitas sistem informasi akuntansi adalah sekumpulan sub sistem fisik dan non fisik yang berkaitan serta bekerjasama untuk mendapatkan informasi yang sesuai dan juga lengkap dengan kebutuhan pengguna untuk mendukung suatu proses bisnis yang disampaikan dan mudah dipahami pengguna.

Jumaili (2005) menyatakan bahwa banyaknya fasilitas komputer perusahaan mempengaruhi terwujudnya efektivitas teknologi sistem informasi akuntansi. Jika menyediakan fasilitas yang lebih banyak kepada pengguna, maka pengguna akan lebih mudah mengoperasikan data yang diperlukan untuk menyelesaikan tugas karyawan. Dengan memakai sistem informasi akuntansi yang efektif, perorangan maupun organisasi yang menggunakannya dapat memperoleh keluaran yang lebih baik dan kinerja yang dihasilkan dapat ditingkatkan.

\section{Indikator Efektivitas Sistem Informasi Akuntansi}

Menurut Wower dan Widhiyani (2012) pengukuran variabel efektivitas sistem informasi akuntansi terdiri dari beberapa indicator yang telah dijabarkan yaitu, keamanan data, waktu, ketelitian, relevansi, variasi laporan atau output, kenyamanan fisik dan kualitas informasi serta teknologi informasi.

\section{Koperasi}

Baswir (2013) menyatakan bahwa, koperasi merupakan suatu bentuk perusahaan yang didirkan oleh orang-orang tertentu, untuk menjalankan suatu usaha berdasarkan ketentuan dan tujuan. Sedangkan menurut Hendar (2010) koperasi merupakan organisasi otonom dari orangorang yang berhimpun secara sukarela untuk melengkapi kebutuhan dan aspirasi ekonomi, social dan budaya secara bersama-sama melalui kegiatan usaha yang dimiliki dan dikendalikan secara demokratis.

\section{METODE PENELITIAN \\ Kerangka Riset}

Kitchenham et al., (2007) mengungkapkan bahwa SLR merupakan proses dari identifikasi, mengevaluasi serta menganalisis semua informasi yang ada untuk menjawab pertanyaan penelitian yang sudah ditentukan.

\section{Objek Penelitian}

Sasaran riset ini ialah, pada koperasi. Mengapa efektivitas sistem informasi akuntansi dijadikan sasaran riset, dikarnakan faktor yang mempengaruhi efektivitas sistem informasi 
akuntansi bermacam-macam serta bisa dijadikan sebagai faktor rekomendasi oleh koperasi guna meningkatkan efektivitas.

\section{Pertanyaan Penelitian}

Pertanyaan penelitian ini dibuat berdasarkan kebutuhan topik yang dipilih, yaitu:

RQ1 : Manakah jurnal yang merupakan jurnal efektivitas sistem informasi akuntansi pada koperasi yang paling signifikan?

RQ2 : Mengenai jurnal efektivitas sistem informasi akuntansi pada koperasi, siapakah peneliti yang paling aktif dan berpengaruh?

RQ 3 : Apa saja faktor-faktor yang dapat mempengaruhi efektivitas sistem informasi akuntansi pada koperasi?

RQ4 : Apa topik dan tren penelitian yang dipilih oleh para peneliti tentang efektivitas sistem informasi akuntansi pada koperasi?

RQ5 : Metode apa yang digunakan untuk mengumpulkan data tentang efektivitas sistem informasi akuntansi pada koperasi?

\section{Proses Pencarian}

Research Process diperlukan untuk mendapatkan sumber-sumber yang terkait langsung dengan persoalan yang diteliti guna menjawab research question. Proses pencarian menggunakan alamat situs https://scholar.google.co.id/ sebagai data sekunder.

String pencarian berikut akhirnya digunakan:

(efektivitas "sistem informasi akuntansi" ATAU kesuksesan sistem informasi akuntansi * ATAU keberhasilan sistem informasi akuntansi) DAN (koperasi)

\section{Kriteria Batasan dan Pemasukan}

Melakukan tahap ini karena berguna untuk memastikan data ataupun informasi yang didapatkan cocok digunakan pada riset (SLR) atau tidak. Standar studi yang memenuhi syarat ialah sebagai berikut:

1. Data yang digunakan dari tahun publikasi 2015-2020.

2. Bukti didapatkan dengan menelusuri http://scholar.google.co.id.

3. Data ataupun bukti yang dipakai hanya paper jurnal yang terkait dengan efektivitas sistem informasi akuntansi koperasi.

\section{Kualitas Penilaian}

Tahapan ini, data yang telah ditemukan akan di evaluasi berdasarkan pertanyaan berikut:

QA1. Apakah paper jurnal diterbitkan pada tahun 2015-2020?

QA2. Apakah paper jurnal membahas efektivitas sistem informasi akuntansi pada

koperasi?

QA3. Apakah pada paper jurnal menuliskan tentang koperasi? penilaian.

Setiap pertanyaan, jurnal yang dipilih akan diberikan penilaian berdasarkan kriteria kualitas

1. Ya : Bagi jurnal yang memenuhi standar kriteria penilaian kualitas.

2. Tidak : Bagi jurnal yang tidak memenuhi standar penilaian kualitas.

\section{Pengumpulan Data}

Bukti yang digunakan dalam riset ini ialah data sekunder.

Data sekunder pada riset ini diperoleh melalui beberapa tahap yaitu: 
1. Literature, dilakukan dengan cara me-review data yang ada pada jurnal dengan metode SLR yang didapatkan dari https://scholar.google.co.id/.

2. Dokumentasi, data yang diperoleh akan disimpan ke dalam Mendeley.

\section{Dokumentasi}

Pada tahap awal hingga hasil penelitian akan dituliskan dalam bentuk paper sesuai format yang telah disediakan.

\section{Peta Pikiran}

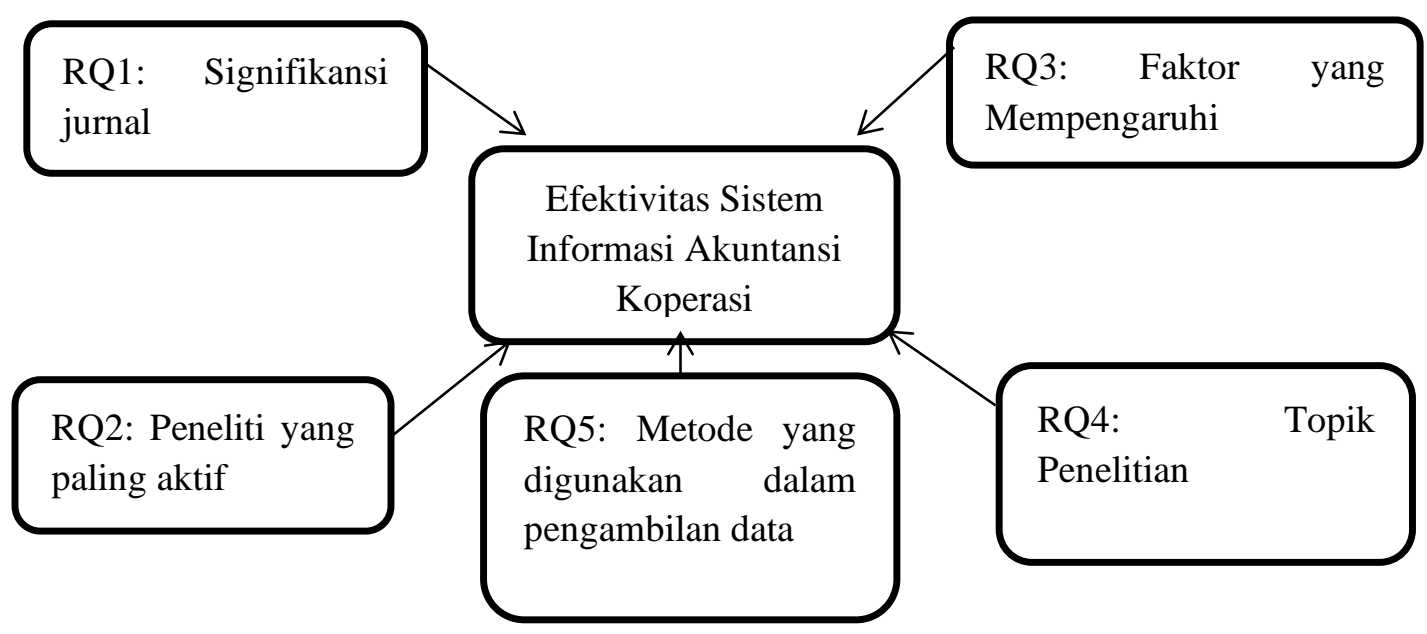

Gambar 1. Peta Pikiran

\section{HASIL DAN PEMBAHASAN}

\section{Hasil Search Process dan Inclusion and Exclusion Criteria}

Hasil dari proses pencarian serta kriteria inklusi dan eksklusi yaitu hanya diambil 10 paper jurnal yang telah sesuai dengan kriteria paper jurnal yang diterbitkan pada rentang waktu 20152020 dan mempunyai pembahasan yang berkaitan dengan efektivitas sistem informasi akuntansi pada koperasi. Sebagaimana terlihat pada tabel 1 dibawah ini:

Tabel 1. Hasil Pencarian Studi

\begin{tabular}{|c|l|l|}
\hline No & Deskripsi & Hasil Penemuan \\
\hline 1 & Studi awal yang ditemukan tahun 2015-2020 & 316 \\
\hline 2 & Studi yang relevan berdasarkan kriteria inklusi dan eksklusi & 15 \\
\hline 3 & Studi yang tidak ditemukan full text & 1 \\
\hline 4 & Studi yang memenuhi kualitas penilaian & 16 \\
\hline \multicolumn{2}{|r|}{ Total studi yang digunakan } & $\mathbf{1 0}$ \\
\hline
\end{tabular}

Sumber: Data diolah, 2021

\section{Hasil dari RQ1: Publikasi Jurnal yang Signifikan}

Penelitian Systematic Literature Review (SLR) ini, terdapat 10 jurnal yang menganalisis efektivitas sistem informasi akuntansi pada koperasi di Indonesia. Pada tahun 2020 banyak jurnal yang membahas mengenai efektivitas sistem informasi akuntansi pada koperasi di Indonesia 
dengan pendekatan kuantitatif. Tahun 2016 tidak ada yang meneliti mengenai efektivitas sistem informasi akuntansi pada koperasi, melainkan pada instansi lain. Pada tahun 2015 dan 2018 masing-masing tahun hanya terdapat satu jurnal yang membahas efektivitas sistem informasi akuntansi koperasi di Indonesia.

Tabel 2. Publikasi Jurnal Yang Signifikan

\begin{tabular}{|l|l|l|l|}
\hline No. & \multicolumn{1}{|c|}{ Nama Penerbit } & Kategori dan Tahun & Jumlah \\
\hline 1 & Jurnal Akuntansi dan Sistem Teknologi Informasi & 2015 & 1 \\
\hline 2 & E-Jurnal Akuntansi Universitas Udayana & $\begin{array}{l}\text { e-ISSN 2302-8556 } \\
(2017)\end{array}$ & 2 \\
\hline 3 & E-Jurnal Akuntansi Universitas Udayana & $\begin{array}{l}\text { e-ISSN 2302-8556 } \\
(2018)\end{array}$ & 1 \\
\hline 4 & Jurnal Akuntansi dan Ekonomika & 2019 & 1 \\
\hline 5 & E-Jurnal Stiedewantara & 2019 & 1 \\
\hline 6 & E-Jurnal Akuntansi & $\begin{array}{l}\text { e-ISSN 2302-8556 } \\
(2020)\end{array}$ & 1 \\
\hline 7 & E-Jurnal Akuntansi Universitas Hindu Indonesia & 2020 & 3 \\
\hline
\end{tabular}

Sumber: Data diolah, 2021

\section{Hasil dari RQ2: Peneliti Aktif dan Berpengaruh}

Studi primer yang telah dipilih, peneliti yang berkontribusi sangat baik dan sangat aktif dalam bidang efektivitas sistem informasi akuntansi pada koperasi di Indonesia dapat diidentifikasi. Pada gambar 4.3 menunjukkan peneliti pertama dan bukan peneliti pertama yang sangat aktif dan juga berpengaruh terhadap efektivitas sistem informasi akuntansi pada koperasi di Indonesia. Indraswarawati (2020) dan Karyada (2020) merupakan peneliti yang paling berpengaruh karena banyak meneliti mengenai efektivitas sistem informasi akuntansi koperasi di Indonesia.

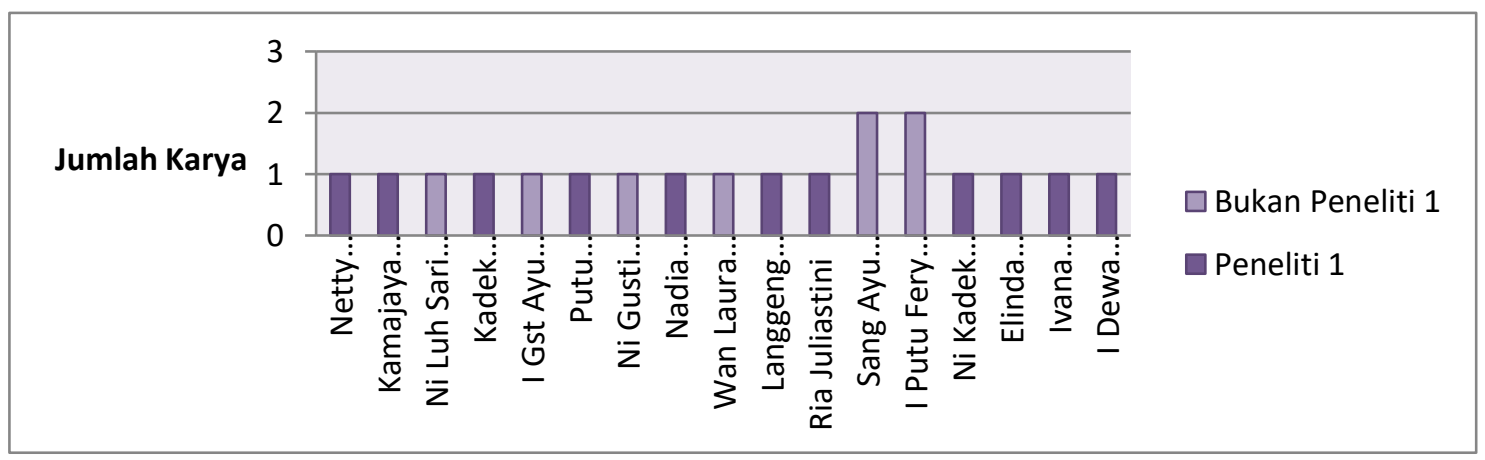

Gambar 2. Peneliti dan Jumlah

\section{Hasil dari RQ 3: Faktor yang Mempengaruhi}

Berdasarkan Research Question 3 mengenai faktor yang mempengaruhi efektivitas sistem informasi akuntansi koperasi, maka dihasilkan kategori paper jurnal berdasarkan faktor yang mempengaruhi. Hasil yang terlihat pada tabel 3 menunjukkan bahwa, keterlibatan pemakai menjadi faktor utama yang sangat mempengaruhi efektivitas sistem informasi akuntansi koperasi. 
Selanjutnya faktor kemampuan teknik personal, kompleksitas tugas, dan dukungan manajer ialah faktor kedua yang mempengaruhi.

Tabel 3. Kategori Faktor yang Mempengaruhi

\begin{tabular}{|c|c|c|c|}
\hline No & Faktor yang Mempengaruhi & Peneliti & Jumlah \\
\hline 1 & Kemampuan Teknik Personal & $\begin{array}{l}\text { (Suartika dan Sari, 2017), (Indrianto dan } \\
\text { Suputra, 2020), (Pardani dan Damayanthi, 2017) }\end{array}$ & 3 \\
\hline 2 & Keterlibatan Pemakai & $\begin{array}{l}\text { (Juliastini, Indraswarawati dan Karyada, 2020), } \\
\text { (Putri dan Karyada, 2020), (Pardani dan } \\
\text { Damayanthi, 2017), (Indrianto dan Suputra, } \\
\text { 2020) }\end{array}$ & 4 \\
\hline 3 & Pemanfaatan Teknologi & $\begin{array}{l}\text { (Netty Febrianingsih, 2015), (Pardani dan } \\
\text { Damayanthi, 2017) }\end{array}$ & 2 \\
\hline 4 & Usia & (Anjani dan Wirawati, 2018) & 1 \\
\hline 5 & Tingkat Pendidikan & (Anjani dan Wirawati, 2018) & 1 \\
\hline 6 & $\begin{array}{l}\text { Program Pelatihan dan } \\
\text { Pendidikan }\end{array}$ & $\begin{array}{l}\text { (Lawita dan Hardilawati, 2019), (Sari dan } \\
\text { Indraswarawati, 2020) }\end{array}$ & 2 \\
\hline 7 & Pengalaman Kerja & $\begin{array}{l}\text { (Anjani dan Wirawati, 2018), (Sari dan } \\
\text { Indraswarawati, 2020) }\end{array}$ & 2 \\
\hline 8 & $\begin{array}{l}\text { Pengetahuan Karyawan di } \\
\text { Bagian Akuntansi }\end{array}$ & (Netty Febrianingsih, 2015), (Utomo, 2019) & 2 \\
\hline 9 & $\begin{array}{l}\text { Kecanggihan Teknologi } \\
\text { Informasi }\end{array}$ & (Utomo, 2019), (Netty Febrianingsih, 2015) & 2 \\
\hline 10 & Kinerja Individu & (Sari dan Indraswarawati, 2020) & 1 \\
\hline 11 & Kompleksitas Tugas & $\begin{array}{l}\text { (Anjani dan Wirawati, 2018), (Juliastini, } \\
\text { Indraswarawati dan Karyada, 2020), (Putri dan } \\
\text { Karyada, 2020) }\end{array}$ & 3 \\
\hline 12 & $\begin{array}{l}\text { Formalisasi Pengembangan } \\
\text { Sistem }\end{array}$ & $\begin{array}{l}\text { (Lawita dan Hardilawati, 2019), (Juliastini, } \\
\text { Indraswarawati dan Karyada, 2020) }\end{array}$ & 2 \\
\hline 13 & Dukungan Manajer & $\begin{array}{l}\text { (Pardani dan Damayanthi, 2017), (Lawita dan } \\
\text { Hardilawati, 2019), (Putri dan Karyada, 2020) }\end{array}$ & 3 \\
\hline 14 & Ukuran Perusahaan & (Lawita dan Hardilawati, 2019) & 1 \\
\hline 15 & $\begin{array}{l}\text { Keberadaan Dewan Pengarah } \\
\text { Sistem Informasi }\end{array}$ & (Lawita dan Hardilawati, 2019) & 1 \\
\hline
\end{tabular}




\begin{tabular}{|l|l|l|l|}
\hline No & Faktor yang Mempengaruhi & Peneliti & Jumlah \\
\hline 16 & $\begin{array}{l}\text { Lokasi Dari Departemen } \\
\text { Pengarah }\end{array}$ & (Lawita dan Hardilawati, 2019) & 1 \\
\hline
\end{tabular}

Sumber: Data diolah, 2021

\section{Hasil dari RQ4: Topik Penelitian}

Penelitian mengenai efektivitas sistem informasi akuntansi koperasi di Indonesia ialah topik penelitian yang signifikan di bidang sistem informasi akuntansi. Analisis studi primer yang dipilih, menjelaskan bahwa penelitian ini berfokus 5 topik yakni:

1. Mengidentifikasi permasalahan tentang efektivitas sistem informasi akuntansi koperasi di Indonesia.

2. Mencari permasalahan terbanyak yang dihadapi oleh efektivitas sistem informasi akuntansi koperasi di Indonesia.

3. Menemukan penyebab terjadinya permasalahan mengenai efektivitas sistem informasi akuntansi koperasi di Indonesia.

4. Memilih solusi jawaban dari permasalahan efektivitas sistem informasi akuntansi koperasi di Indonesia.

5. Membuat kesimpulan mengenai solusi jawaban terlengkap dan terbaik dari semua penelitian tentang efektivitas sistem informasi akuntansi koperasi di Indonesia.

Topik pertama yaitu mengidentifikasi permasalahan efektivitas sistem informasi akuntansi koperasi di Indonesia, Suartika dan Sari (2017), Indrianto dan Suputra (2020) dan Pardani dan Damayanthi (2017), meneliti pentingnya kemampuan teknik personal, sedangkan Juliastini, Indraswarawati dan Karyada (2020), Putri dan Karyada (2020), Pardani dan Damayanthi (2017), Indrianto dan Suputra (2020) membahas tentang keterlibatan pemakai. Febrianingsih (2015) dan Pardani dan Damayanthi (2017) meneliti pentingnya pemanfaatan teknologi, Anjani dan Wirawati (2018) membahas tentang usia dan pentingnya tingkat pendidikan, sedangkan Lawita dan Hardilawati (2019) dan Sari dan Indraswarawati (2020) meneliti mengenai pentingnya program pelatihan dan pendidikan karyawan. Anjani dan Wirawati (2018) dan Sari dan Indraswarawati (2020) membahas tentang pengalaman kerja, Febrianingsih (2015) dan Utomo (2019) membahas tentang pentingnya pengetahuan karyawan di bagian akuntansi dan kecanggihan teknologi informasi dan Sari dan Indraswarawati (2020) menyoroti tentang kinerja individu. Anjani dan Wirawati (2018), Juliastini, Indraswarawati dan Karyada (2020), dan Putri dan Karyada (2020) meneliti tentang kompleksitas tugas, Lawita dan Hardilawati (2019) dan Juliastini, Indraswarawati dan Karyada (2020) meneliti tentang formalisasi pengembangan sistem. Pardani dan Damayanthi (2017), Lawita dan Hardilawati (2019), dan Putri dan Karyada (2020) meneliti tentang pentingnya dukungan manajer, sedangkan Lawita dan Hardilawati (2019) membahas tentang ukuran perusahaan, keberadaan dewan pengarah sistem informasi, dan lokasi dari departemen pengarah.

Pembahasan topik kedua mengenai permasalahan terbanyak yang dihadapi oleh efektivitas sistem informasi akuntansi koperasi di Indonesia adalah tentang keterlibatan pemakai yang dibahas oleh Juliastini, Indraswarawati dan Karyada (2020), Putri dan Karyada (2020), Pardani dan Damayanthi (2017), Indrianto dan Suputra (2020). Permasalahan yang lain adalah kompleksitas tugas yang diteliti oleh Anjani dan Wirawati (2018), Juliastini, Indraswarawati dan Karyada (2020), dan Putri dan Karyada (2020) dan dukungan manajer yang diteliti oleh Pardani dan Damayanthi (2017), Lawita dan Hardilawati (2019), dan Putri dan Karyada (2020). 
Topik ketiga menemukan penyebab terjadinya permasalahan efektivitas sistem informasi akuntansi koperasi di Indonesia yaitu, kurangnya pengetahuan yang dimiliki pemakai sehingga pemakai tidak bersedia dalam membuat keputusan. Hal ini disebabkan karena, pelatihan dan pendidikan yang diberikan koperasi masih sulit dipahami pemakai, sehingga banyak pemakai yang belum mengerti materi pelatihan dan pengetahuan yang diberikan (Pardani dan Damayanthi, 2017). Indrianto dan Suputra (2020) juga mengatakan bahwa, pentingnya pelatihan memperkuat pengaruh keterlibatan pemakai.

Topik keempat memilih solusi jawaban dari permasalahan efektivitas sistem informasi akuntansi koperasi di Indonesia. Pardani dan Damayanthi (2017) mengatakan perlu memberikan pendidikan serta pelatihan program sistem informasi akuntansi untuk dapat meningkatkan keahlian yang dimiliki karyawan, sama dengan pendapat Sari dan Indraswarawati (2020) selain itu, memberikan materi pelatihan dan pendidikan yang mudah dipahami oleh karyawan, serta memberikan motivasi kepada karyawan untuk memahami sistem informasi akuntansi lebih baik lagi. Juliastini, Indraswarawati dan Karyada (2020) dengan jurnal yang berbeda namun topiknya masih sama mengenai efektivitas sistem informasi akuntansi juga menjawab permasalahan kurangnya pengetahuan yang dimiliki pemakai yaitu dengan cara, pemakai untuk lebih mempelajari dalam penggunaan sistem informasi akuntansi dan bukan hanya menggunakan untuk menyelesaikan pekerjaanya saja, sehingga dapat menambah pengalaman dan wawasan terhadap sistem informasi tersebut. Indrianto dan Suputra (2020) dengan jurnal yang berbeda namun topiknya masih sama juga menjawab permasalahan kurangnya pengetahuan yang dimiliki pemakai, karyawan perlu mendapatkan pelatihan lebih lanjut untuk dapat mengefektivkan penggunaan sistem informasi akuntansi dalam menghasilkan laporan keuangan yang berkualitas dan mampu meningkatkan kemampuan teknik personal serta keterlibatan pemakai. Juliastini, Indraswarawati dan Karyada (2020) untuk menjawab masalah kompleksitas tugas, maka koperasi perlu memberikan tugas kepada karyawan secara berkelompok sehingga tugas dapat diselesaikan secara bersama untuk hasil yang lebih cepat dan baik. Pardani dan Damayanthi (2017) untuk menjawab masalah dukungan manajer, minimnya ketersediaan fasilitas yang diberikan oleh manajer koperasi maka perlu adanya dukungan manajemen untuk memotivasi individu dalam menggunakan sistem dengan perhatian dan dukungan sumberdaya finansial dan nonfinansial serta pelatihan-pelatihan agar individu dapat memahami penggunaan sistem sedangkan solusi lain juga dikemukakan oleh Putri dan Karyada (2020) dengan cara manajer mengeluarkan kebijakan yang lebih mendukung untuk pengembangan sistem informasi yang dapat memudahkan kerja karyawan.

Topik kelima ialah solusi jawaban terlengkap dan terbaik dari semua penelitian tentang efektivitas sistem informasi akuntansi yaitu meningkatkan pengetahuan karyawan dengan cara memberikan program pelatihan dan pendidikan sistem informasi akuntansi (Utomo, 2019) ; (Suartika dan Sari, 2017) digabungkan dengan memberikan motivasi kepada karyawan untuk memahami sistem informasi akuntansi lebih baik lagi (Sari dan Indraswarawati, 2020). Untuk mencapai tujuan tersebut, maka perlu adanya dukungan manajer yang dapat membuat sistem kerjasama lebih bermanfaat agar dapat mendukung, memengaruhi, mengarahkan dan berkomunikasi, dengan para bawahannya yang akan mendukung peningkatan efektivitas sistem informasi akuntansi (Pardani dan Damayanthi, 2017).

\section{Hasil dari RQ5: Teknik Pengumpulan Data}

Berdasarkan teknik pengumpulan data untuk penelitian mengenai efektivitas sistem informasi akuntansi koperasi di Indonesia, diperoleh hasil yaitu kategori paper berdasarkan teknik 
pengumpulan datanya. Tabel 4 menunjukkan bahwa, semua penelitian menggunakan teknik pengumpulan data kuesioner. Hal ini menunjukkan bahwa, kebanyakan peneliti saat ini lebih tertarik meneliti menggunakan metode kuesioner dibandingkan metode yang lain. Jumlah responden terbanyak yaitu 108 yang diteliti oleh Suartika dan Sari (2017).

Tabel 4. Kategori Teknik Pengumpulan Data

\begin{tabular}{|c|c|c|c|c|}
\hline No & Teknik Pengumpulan Data & $\begin{array}{l}\text { Jumlah } \\
\text { Responden }\end{array}$ & Peneliti & Jumlah \\
\hline \multirow[t]{10}{*}{1.} & \multirow[t]{10}{*}{ Kuesioner } & 20 & (Netty Febrianingsih, 2015) & 1 \\
\hline & & 56 & (Utomo, 2019) & 1 \\
\hline & & 65 & (Sari dan Indraswarawati, 2020) & 1 \\
\hline & & 69 & (Anjani dan Wirawati, 2018) & 1 \\
\hline & & 72 & (Indrianto dan Suputra, 2020) & 1 \\
\hline & & 83 & (Putri dan Karyada, 2020) & 1 \\
\hline & & 90 & $\begin{array}{l}\text { (Juliastini, Indraswarawati dan } \\
\text { Karyada, 2020) }\end{array}$ & 1 \\
\hline & & 95 & (Lawita dan Hardilawati, 2019) & 1 \\
\hline & & 100 & (Pardani dan Damayanthi, 2017) & 1 \\
\hline & & 108 & (Suartika dan Sari, 2017) & 1 \\
\hline
\end{tabular}

Sumber: Data diolah, 2021

\section{KESIMPULAN \\ Simpulan}

Berdasarkan hasil penelitian yang sudah dilakukan, maka dapat diambil kesimpulan bahwa penelitian yang dilakukan menggunakan metode Systematic Literature Review dan bertujuan untuk mengidentifikasi dan menganalisis signifikansi jurnal, peneliti yang paling aktif, faktor yang mempengaruhi, topik dan tren penelitian, serta metode yang digunakan dalam pengambilan data. Terdapat 10 jurnal yang diperoleh berdasarkan hasil seleksi pencarian studi. Faktor yang mempengaruhi efektivitas sistem informasi akuntansi koperasi di Indonesia ialah adanya faktor kemampuan teknik personal, keterlibatan pemakai, pemanfaatan teknologi, usia, tingkat pendidikan, program pelatihan dan pendidikan, pengalaman kerja, pengetahuan karyawan di bagian akuntansi, kecanggihan teknologi informasi, kinerja individu, kompleksitas tugas, formalisasi pengembangan sistem, dukungan manajer, ukuran perusahaan, keberadaan dewan pengarah serta lokasi dari departemen pengarah.

Hasil dari research question (RQ:1) pada publikasi jurnal yang signifikan bahwa tahun 2016 tidak ada yang meneliti mengenai efektivitas sistem informasi akuntansi pada koperasi melainkan pada perusahaan lain. Pada tahun 2015 dan 2018 masing-masing tahun hanya ditemukan satu jurnal yang mengulas efektivitas sistem informasi akuntansi pada koperasi. Selanjutnya research question (RQ:2) peneliti aktif dan berpengaruh yaitu (Indraswarawati, 2020) dan (Karyada, 2020) yang merupakan bukan peneliti satu yang paling aktif dan berpengaruh karena banyak meneliti tentang efektivitas sistem informasi akuntansi koperasi di Indonesia.

Selanjutnya untuk research question (RQ:3) pada faktor yang mempengaruhi diperoleh bahwa keterlibatan pemakai merupakan faktor utama yang mempengaruhi dan faktor kemampuan teknik personal, kompleksitas tugas, serta dukungan manajer ialah faktor kedua yang mempengaruhi. Hasil dari research question (RQ:4) untuk topik penelitian yang paling sering 
yaitu tentang keterlibatan pemakai dimana koperasi sebaiknya memberikan pendidikan serta pelatihan program sistem informasi akuntansi sehingga dapat meningkatkan keahlian yang dimiliki pemakai dan mampu dalam membuat keputusan. Research Question (RQ:5) mengenai teknik pengumpulan data, semua penelitian menggunakan metode kuesioner dibandingkan metode yang lainnya.

\section{Saran}

Systematic Literature Review ini memiliki keterbatasan yaitu, penelitian ini umumnya didasarkan pada kata kunci terbatas dan juga oleh database google scholar yang digunakan untuk koleksi paper jurnal pada tahun 2015-2020. Penelitian selanjutnya, disarankan untuk menggunakan sampel yang lebih banyak dengan memperluas kata kunci yang digunakan dan database lain yang mudah di akses. Hal ini, juga dapat digunakan sebagai perbandingan hasil analisis yang berbeda mengenai Systematic Literature Review efektivitas sistem informasi akuntansi koperasi serta mampu memberikan penjelasan lebih rinci. 


\section{REFERENSI}

Anjani, P. W. dan Wirawati, N. G. P. (2018) 'Pengaruh Usia, Pengalaman Kerja, Tingkat Pendidikan, dan Kompleksitas Tugas terhadap Efektivitas Pengguna Sistem Informasi Akuntansi', E-Jurnal Akuntansi. ocs.unud.ac.id.

Baswir, R. (2013) 'Koperasi Indonesia edisi kedua', Yogyakarta: BPFE.

Bodnar, G. H. dan Hopwood, W. S. (2006) 'Sistem informasi akuntansi', Jakarta: Salemba Empat.

Damayanthi, I. G. A. (2012). Pengaruh Efektivitas Sistem Informasi Akuntansi Dan PenggunaanTeknologi Informasi Terhadap Kinerja Individual Pada Koperasi Simpan di Kecamatan Denpasar Barat', Jurnal Riset Akuntansi Juara.

Diana, A. dan Setiawati, L. (2011) 'Sistem Informasi Akuntansi, Yogyakarta'. Andi.

Dwijayanthi, D. M. and Dharmadiaksa, I. B. (2013) 'Pengaruh Insentif, Tingkat Pendidikan, Pelatihan dan Pengalaman Kerja pada Kinerja Individu Pengguna Sistem Informasi Akuntansi SKPD Dispenda Kota Denpasar', Universitas Udayana Denpasar: EJurnal Akuntansi. ojs.unud.ac.id.

Emeka-Nwokeji, N. A. (2012) 'Repositioning accounting information system through effective data quality management: A framework for reducing costs and improving performance', International Journal of Scientific \& Technology Research Volume 1 Citeseer. Available at: http://citeseerx.ist.psu.edu/viewdoc/download?doi=10.1.1.299.7921\&rep=rep1\&type $=$ pdf.

Febrianingsih, Netty (2015) 'Pengaruh Pemanfaatan Teknologi Informasi Dan Pengetahuan Karyawan Bagian Akuntansi Terhadap Efektivitas Sistem Informasi Akuntansi Dengan Pelatihan Sebagai Variabel Kontrol', Jurnal Akuntansi dan Sistem Teknologi Informasi, 11(2), pp. 218-225.

Halimatusadiah, E., Nurhayati, N. dan Rayandani, ER (2015) Effects of top management support, education and training on the effectiveness of accounting information system (survey on government-owned insueance companies in bandung) repository.unisba.ac.id. Available at: http://repository.unisba.ac.id/handle/123456789/1099.

Hendar, S. E. dan Si, M. (2010) 'Manajemen Perusahaan Koperasi', Jakarta: Penerbit Erlangga.

Hla, D. and Teru, S. P. (2015) 'Efficiency of accounting information system and performance measures', ... Journal of Multidisciplinary and Current Research ISSN: 2321-3124. researchgate.net.

Indrianto, I. E. dan Suputra, I. (2020) 'Pengaruh Kemampuan Teknik Personal dan Keterlibatan Pemakai pada Efektivitas Penggunaan SIA dengan Pelatihan sebagai Variabel Pemoderasi', E-Jurnal Akuntansi. Available at: https://ocs.unud.ac.id/index.php/Akuntansi/article/view/60104. 
Juliastini, R., Indraswarawati, S. dan Karyada (2020) 'Pengaruh Formalisasi Pengembangan Sistem, Partisipasi Pemakai, Dan Kompleksitas Tugas Terhadap Efektivitas Penerapan Sistem Informasi Akuntansi Pada Koperasi Serba Usaha di Kecamatan Kintamani, Bangli', Hita Akuntansi dan Keuangan, 1 (1), 186-203 Available at: https://ejournal.unhi.ac.id/index.php/HAK/article/view/775.

Jumaili, S. (2005) 'Kepercayaan terhadap teknologi sistem informasi baru dalam evaluasi kinerja individual', Solo: Simposium Nasional Akuntansi VIII.

Kharisma, M. D. and Dharmadiaksa, I. B. (2015) 'Pengaruh Keterlibatan Pengguna Dan Ukuran Organisasi Pada Efektivitas Penggunaan Sistem Informasi Akuntansi’, Jurnal Ilmiah. Universitas Udayana.

Kitchenham, B. et al. (2007) 'A systematic literature review of evidence-based software engineering', in Information \& Software ....

Kitchenham, B., Mendes, E. and ... (2007) 'A systematic review of cross-vs. within-company cost estimation studies', ... on Evaluation and ....

Krisiani, V. dan Dewi, A. F. (2013) 'Pengaruh Efektivitas Dan Kepercayaan atas Sistem Informasi Akuntansi Terhadap Kinerja Pengguna Sistem pada Hotel-hotel Berbintang di Yogyakarta', MODUS. ISSN.

Lawita, N. F. dan Hardilawati, W. L. (2019) 'Faktor-faktor yang mempengaruhi kesuksesan penggunaan sistem informasi akuntansi di Koperasi Kota Pekanbaru', Jurnal Akuntansi dan Ekonomika. Available at: http://ejurnal.umri.ac.id/index.php/jae/article/view/1464.

Novita, H. (2011) Efektivitas Sistem Informasi Akuntansi Dampaknya Terhadap Kinerja Karyawan Pada PT. Dwi Daya Sentra Prakasa (persero). repository.unikom.ac.id. Available at: https://repository.unikom.ac.id/18145/.

Nurdin, I. dan Hartati, S. (2019) Metodologi Penelitian Sosial. books.google.com.

Pardani, K. K. dan Damayanthi, I. (2017) 'Pengaruh Pemanfaatan Teknologi, Partisipasi Pemakai, Manajemen Puncak dan Kemampuan Pemakai Terhadap Efektivitas Sistem Informasi Akuntansi', E-Jurnal Akuntansi Universitas Udayana.

Putri, N. dan Karyada, I. P. F. (2020) 'Pengaruh Keterlibatan Pemakai, Kompleksitas Tugas Dan Dukungan Manajer Terhadap Efektivitas Penerapan Sistem Informasi ...', Hita Akuntansi dan Keuangan. Available at: https://ejournal.unhi.ac.id/index.php/HAK/article/view/1012.

Ramazani, M. and Allahyari, A. (2013) 'Compatibility and Flexibility of Accounting Information Systems', ... of Emerging Trends in Computing and Information Science Vol 4, No 3. Available at: https://papers.ssrn.com/sol3/papers.cfm?abstract_id=2245993. 
Ratnaningsih, K. I. dan Suaryana, I. (2014) 'Pengaruh kecanggihan teknologi informasi, partisipasi manajemen, dan pengetahuan manajer akuntansi pada efektivitas sistem informasi akuntansi', E-Jurnal Akuntansi. Available at: https://ocs.unud.ac.id/index.php/Akuntansi/article/view/7775.

Romney, M. B. dan Steinbart, P. J. (2016) 'Sistem Informasi Akuntansi, Edisi 13, cetakan keempat', Jakarta. Selemba Empat.

Sari, E. N. and Indraswarawati, S. (2020) 'Pengaruh Program Pelatihan Dan Pendidikan, Kinerja Individu Dan Pengalaman Kerja Personal Terhadap Efektivitas Penggunaan Sistem Informasi Akuntansi', Hita Akuntansi dan Keuangan.

Suartika, K. A. dan Sari, W. N. L. (2017) 'Kemampuan Teknik Personal Pada Efektivitas Penggunaan Sistem Informasi Akuntansi Dengan Pendidikan Dan Pelatihan Sebagai Pemoderasi', E-Jurnal Akuntansi Universitas Udayana. ojs.unud.ac.id.

Sugiyono, P. (2014) 'Metode Kuantitatif Kualitatif dan R \& D', Jakarta: Alfabeta.

Susanto, A. (2017) 'Sistem Informasi Manajemen: Konsep dan Pengembangan Secara Terpadu', Bandung: Lingga Jaya.

Tata, S. (2012) ‘Analisis Sistem Informasi’, Yogyakarta: Andi.

Triandini, E. et al. (2019) 'Metode Systematic Literature Review untuk Identifikasi Platform dan Metode Pengembangan Sistem Informasi di Indonesia', Indonesian Journal of .... Available at: http://ojs.uajy.ac.id/index.php/IJIS/article/view/1916.

Trino, J. (2013) 'Penerapan Sistem Informasi Pada Koperasi Simpan Pinjam', Agri-tek. unmermadiun.ac.id.

Utomo, L. P. (2019) 'Pengaruh Kecanggihan Teknologi Informasi Dan Pengetahuan Karyawan Bagian Akuntansi Terhadap Efektivitas Sistem Informasi Akuntansi', E-Journal STIE Dewantara, 8(2), p. 2019. doi: 10.22201/fq.18708404e.2004.3.66178.

Wower, S. dan Widhiyani, N. L. S. (2012) 'Penilaian Efektivitas Penerapan Sistem Informasi Akuntansi Berbasis Komputer pada SKPD Pemkab Tabanan’, E-Jurnal Akuntansi Universitas Udayana. 